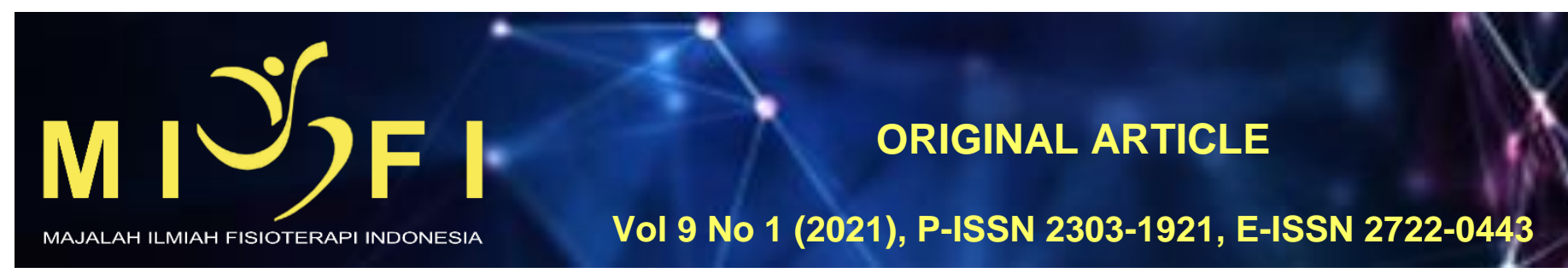

\title{
HUBUNGAN ANTARA INDEKS MASSA TUBUH (IMT) DENGAN KEBUGARAN JASMANI PADA SISWI SMA NEGERI 2 TABANAN
}

\author{
Miqdaddiati ${ }^{1}$, Ni Luh Nopi Andayani ${ }^{2}$, I Dewa Ayu Dwi Primayanti ${ }^{3}$, Luh Made Indah Sri Handari Adiputra ${ }^{4}$ \\ ${ }^{1}$ Program Studi Sarjana Fisioterapi dan Profesi Fisioterapi, Fakultas Kedokteran Universitas Udayana, Denpasar, Bali \\ ${ }^{2}$ Departemen Fisioterapi, Fakultas Kedokteran Universitas Udayana, Denpasar, Bali \\ ${ }^{3,4}$ Departemen Fisiologi, Fakultas Kedokteran Universitas Udayana, Denpasar, Bali \\ dyanmiqdaddiati2297@gmail.com
}

\begin{abstract}
ABSTRAK
Kebugaran Jasmani merupakan manfaat yang sangat penting bagi kehidupan seseorang dalam melakukan kegiatan sehari-hari. Kebugaran jasmani adalah kondisi jasmani yang bersangkut paud dengan kemampuan dan kesanggupannya berfungsi dalam pekerjaan secara optimal dan efisien. Tujuan penelitian adalah untuk mengetahui hubungan antara indeks massa tubuh (IMT) dengan kebugaran jasmani pada siswi SMA Negeri 2 di tabanan. Penelitian ini ialah penelitian analitik cross sectional yang dilakukan pada bulan Mei 2019 pengambilan sampel dilakukan secara simple random sampling. Jumlah sampel ialah 62 orang dengan usia 15-17 tahun. Variable Independen yang diukur adalah indeks massa tubuh (IMT) melalui pengukuran dengan mengukur tinggi badan (TB) dan berat badan (BB) sedangkan variable dependen yang diukur adalah kebugaran jasmani melalui Harvard Step Test. Uji hipotesis yang digunakan ialah uji analisis non parametik Chi Square Test dan uji analisis deskriptif untuk mendeskripsikan setiap variable dalam penelitian didapatkan nilai $P$ ialah 0.039 atau $p<0.05$, maka dapat disimpulkan bahwa ditemukan hubungan yang signifikan antara indeks massa tubuh (IMT) dengan kebugan jasmani pada siswi SMA Negeri 2 Tabanan.
\end{abstract}

Kata Kunci: Indeks Massa Tubuh (IMT), Kebugaran Jasmani

\section{THE CORRELATION BETWEEN BODY MASS INDEX (BMI) WITH PHYSICAL FITNESS IN SMA NEGERI 2 TABANAN}

\section{ABSTRACT}

Physical fitness is a very important benefit for one's life in performing daily activities. Physical fitness is a physical condition which is related to the ability and ability to function at work optimally and efficiently. The research objective is to determine the relationship between body mass index (BMI) with physical fitness in SMA Negeri 2 Tabanan. This study is a cross-sectional analytic study conducted in May 2019 sampling is done by simple random sampling. The number of samples is 62 people with ages 15-17 years. Independent variables measured were body mass index (BMI) through measurement by measuring the height (TB) and body weight (BW), while the dependent variable is measured the physical fitness through the Harvard Step Test. Hypothesis test used is non-parametric analysis test Chi Square test and analysis test descriptive to describe each variable in the research showed the $p$ value is 0.039 or $p<0.05$, then it can be concluded that found a significant correlation between body mass index (BMI) with physical fitness on SMA Negeri 2 Tabanan.

Keyword: Body Mass Index (BMI), Physical Fitness

\section{PENDAHULUAN}

Kebugaran jasmani adalah bentuk kemampuan seseorang untuk melakukan pekerjaan dengan efisien tanpa menimbulkan kelelahan yang berarti. ${ }^{1}$ Bahwa melalui kebugaran jasmani yang baik, setiap siswa akan memiliki rasa percaya diri dalam kegiatan menuntut ilmu karena ia tidak akan mudah lelah, tidak mudah kehilangan konsentrasi, ataupun tidak mudah jatuh sakit karena daya tahan tubuh menurun sehingga akibatnya siswa akan mampu menunjukkan potensi maksimalnya dan mampu bersaing dengan siswa lain baik itu dalam skala regional, nasional maupun internasional.

Anak yang memiliki indeks massa tubuh (IMT) yang normal dan mendapat asupan gizi yang baik dapat mempengaruhi penerimaan dalam hal nutrisi yaitu Karbohidrat, Lemak, Protein. Fungsi dari nutrisi tersebut dapat membantu anak dalam beraktivitas. Selama beraktivitas diperlukan energi. Bagi anak yang memiliki asupan gizi kurang dapat mempengaruhi tingkat kebugaran anak tersebut, sedangkan anak yang mendapat asupan gizi yang baik maka tingkat kebugarannya akan baik. Pada remaja usia 13-15 tahun di Daerah Istimewa Yogyakarta memiliki prevalensi status gizi sangat kurus $3,1 \%$, kurus $7,6 \%$, normal $86,8 \%$ dan gemuk $2,6 \%$. Indeks massa tubuh (IMT) merupakan kriteria yang paling banyak digunakan untuk melihat status obesitas pada anak dan remaja.

Terdapat berbagai faktor yang dapat mempengaruhi kebugaran jasmani, antara lain umur,jenis kelamin, genetik, ras, aktivitas fisik. Faktor yang mempengaruhi indeks massa tubuh (IMT) adalah usia, jenis kelamin, genetik, dan aktivitas fisik. Kebugaran jasmani merupakan suatu keadaan dinamis antara energy dan vitalitas yang memungkinkan seseorang untuk melakukan tugas sehari-hari dalam keadaan darurat yang tidak terduga tanpa 
mengalami kelelahan yang berlebih. Anak-anak dan remaja sangat memerlukan kebugaran jasmani untuk dapat melakukan aktivitas fisik yang cukup padat, baik aktivitas yang dilakukan disekolah maupun diluar sekolah. Indeks massa tubuh (IMT) merupakan proses menentukan kelebihan berat badan yang berdasarkan berat badan (BB) dan tinggi badan $(\mathrm{TB})$. $^{2}$

Kebugaran jasmani yang baik akan mempengaruhi kemampuan siswi dalam menerima dan menyerap pelajaran yang diberikan oleh guru sehingga dapat terciptanya generasi penerus bangsa yang unggul dalam aspek akan dapat terealisasikan. Kebugaran jasmani yang kurang baik, bagus akan berdampak terhadap kualitas dalam melakukan aktivitas sehari-hari. Kebugaran jasmani adalah sebagai suatu keadaan yang dimiliki seseorang yang berhubungan dengan kemampuan untuk melakukan aktivitas fisik dimana didalam penelitian ini diukur dengan Harvard Step Test dengan cara naik turun bangku selama 5 menit. Kategori kebugaran jasmani dibagi menjadi baik sekali (2225), baik (18-21), sedang (14-17), kurang (10-13), kurang sekali (6-9). ${ }^{3}$

Menurut penelitian sebelumnya menunjukan bahwa terdapat hubungan negatif yang sedang antara indeks massa tubuh (IMT) dengan tingkat kebugaran jasmani pada laki-laki, dan hubungan negatif yang lemah antara indeks massa tubuh (IMT) dengan tingkat kebugaran jasmani pada anak perempuan. Pada anak laki-laki didapatkan hubungan yang sedang antara indeks massa tubuh (IMT) dengan komponen kecepatan, daya ledak otot, ketangkasan, daya tahan otot perut, dan daya tahan kardiorespirasi. Sedangkan tidak didapatkan hubungan antara indeks massa tubuh (IMT) dengan kelenturan dan komponen kekuatan statis dan daya tahan otot pada anak laki-laki. Pada anak perempuan didapatkan hubungan yang lemah antara indeks massa tubuh (IMT) dengan komponen kecepatan, kekuatan statis dan daya tahan otot lengan/bahu, ketangkasan, daya tahan otot perut, serta daya tahan kardiorespirasi. Tidak didapatkan juga hubungan indeks massa tubuh (IMT) dengan daya ledak otot dan kelenturan pada anak perempuan dan tidak terdapat hubungan antara tingkat kebugaran jasmani dengan aktivitas fisik, umur, jenis kelamin, dan latihan. Sebagian besar subyek memiliki tingkat kebugaran jasmani kurang. ${ }^{4}$

Dampak dari kebugaran jasmani pada anak-anak, remaja ialah kurang aktif bergerak karena keterbatasan waktu dan kesempatan untuk berlatih jasmani, karena melakukan permainan di laptop, video games, dan disertai pula dengan pola makan yang tidak sehat sehingga beresiko menurunkan fungsi organ (degeneratif). Terdapat indeks massa tubuh (IMT) dengan kategori obesitas dapat menyebabkan kebugaran jasmani kurang baik atau terhambat dalam melakukan aktifitas sehari-hari pada siswi, sehingga mudah mengalami kelelahan yang berlebihan. ${ }^{5}$

Penilaian kebugaraan jasmani yang digunakan pada penelitian ini adalah Harvard Step Test. Terdapat 10 komponen dalam kebugaran jasmani, yaitu kekuatan otot, daya tahan otot, kelenturan, kebugaran jasmani kardiorespirasi, komposisi tubuh, ketangkasan, kecepatan, koordinasi atau keterampilan, daya ledak, keseimbangan. Dalam penelitian ini dilakukan penilain indeks massa tubuh (IMT) dengan mengukur tinggi badan (TB) dan dibagi dengan berat badan (BB). Pada penelitian ini menjelaskan bahwa indeks massa tubuh (IMT) dengan kategori obesitas maka dapat mempengaruhi kebugaran jasmani yang kurang.

Pengukuran indeks massa tubuh (IMT) yaitu dengan rumus berat badan (BB) dibagi tinggi badan (TB) kuadrat $\left(\mathrm{kg} / \mathrm{m}^{2}\right)$. Indeks massa tubuh (IMT) yang digunakan pada penelitian ini ialah dengan kategori indeks massa tubuh (IMT) underweight berada dibawah angka $<17 \mathrm{~kg} / \mathrm{m} 2$, berat badan lebih atau overweight berada di $>23-27 \mathrm{~kg} / \mathrm{m} 2$, indeks massa tubuh (IMT) obesitas berada di antara $>27 \mathrm{~kg} / \mathrm{m} 2$ dan indeks massa tubuh (IMT) normal berada antara 17-23 $\mathrm{kg} / \mathrm{m} 2$, pada siswi SMA Negeri 2 tabanan dengan umur 15-17 tahun di Tabanan. ${ }^{6}$

Hingga saat ini belum banyak penelitian yang meneliti mengenai hubungan antara indeks massa tubuh (IMT) dengan kebugaran jasmani pada siswi. Berdasarkan latar belakang diatas, maka peneliti tertarik untuk melakukan penelitian dengan judul Hubungan Antara Indeks Massa Tubuh (IMT) Dengan Kebugaran Jasmani Pada Siswi SMA Negeri 2 Tabanan.

\section{METODE}

Rancangan penelitian yang digunakan adalah analitik cross sectional. Penelitian dilaksanakan pada bulan Mei 2019 di SMA Negeri 2 Tabanan. Sampel penelitian yaitu siswi SMA Negeri 2 Tabanan yang sesuai dengan kriteria inklusi dan eksklusi dengan menggunakan simple random sampling. Sampel berjumlah 62 siswi.

Variabel dependen dalam penelitian ini yaitu kebugaran jasmani, variabel independen adalah indeks massa tubuh (IMT). Analisis data pada penelitian ini menggunakan SPSS dengan menggunakan analisis univariat untuk mengetahui kebugaran jasmani, indeks massa tubuh (IMT) dan analisis bivariat untuk mengetahui hubungan 2 variabel dengan menggunakan Uji Chi-Square Test dengan tingkat signifikansi yang digunakan yaitu $p=0,05$.

HASIL

Dibawah ini merupakan karakteristik sampel berdasarkan usia sebagai berikut:

Table 1. Distribusi Frekuensi Berdasarkan Usia

\begin{tabular}{ccc}
\hline Kelompuk Usia (tahun) & Frekuensi (f) & Presentase (\%) \\
\hline 15 tahun & 12 & 19,4 \\
16 tahun & 42 & 67,7 \\
17 tahun & 8 & 12,9 \\
\hline Jumlah & 62 & 100,0 \\
\hline
\end{tabular}

Berdasarkan Tabel 1. diketahui responden terbanyak ialah pada usia 16 tahun yaitu sejumlah 42 orang (67,7\%), pada usia 15 tahun sejumlah 12 orang $(19,4 \%)$ dan pada usia 17 tahun sejumlah 8 orang $(12,9)$. 
Table 2. Distribusi Frekuensi Berdasarkan Indeks Massa Tubuh (IMT)

\begin{tabular}{ccc}
\hline Kategori & Frekuensi & Persentase (\%) \\
\hline Underweight & 6 & 9,7 \\
Normal & 38 & 61,3 \\
Overweight & 13 & 21,0 \\
Obesitas & 5 & 8,1 \\
\hline Total & 62 & 100 \\
\hline
\end{tabular}

Berdasarkan Tabel 2. dilihat bahwa dari 62 orang memiliki indeks massa tubuh (IMT) yang normal sejumlah 38 orang $(61,3 \%)$ sedangkan responden yang mempunyai indeks massa tubuh (IMT) yang obesitas sejumlah 5 orang $(8,1 \%)$.

Table 3. Distribusi Frekuensi Berdasarkan Kebugaran Jasmani

\begin{tabular}{ccc}
\hline Kategori & Frekuensi & Persentase $(\%)$ \\
\hline Kurang & 2 & 3,2 \\
Sedang & 8 & 12,9 \\
Baik & 10 & 16,1 \\
Baik sekali & 42 & 67,7 \\
\hline Total & 62 & 100 \\
\hline
\end{tabular}

Berdasarkan table 3. diatas, dari 62 siswi menunjukan bahwa rata-rata kebugaran jasmani siswi usia 15-17 tahun adalah untuk kategori kurang sebanyak 2 siswi $(3,2 \%)$, sedang sebanyak 8 siswi $(12,9 \%)$, baik sebanyak 10 siswi (16,1\%), dan baik sekali sebanyak 42 siswi $(67,7 \%)$.

Table 4. Distribusi Hubungan Indeks Massa Tubuh (IMT) dengan Kebugaran Jasmani

\begin{tabular}{|c|c|c|c|c|c|c|}
\hline \multirow{2}{*}{ IMT } & \multicolumn{4}{|c|}{ Kebugaran jasmani } & \multirow[b]{2}{*}{ Total } & \multirow[b]{2}{*}{$p$} \\
\hline & Kurang & Sedang & Baik & Baik sekali & & \\
\hline Underweight & $0(0 \%)$ & $1(16,7 \%)$ & $2(33,3 \%)$ & $3(50,0 \%)$ & $6(100,0 \%)$ & \\
\hline Normal & $1(2,6 \%)$ & $4(10,5 \%)$ & $3(7,9 \%)$ & $30(78,9 \%)$ & $38(100,0 \%)$ & \\
\hline Overweight & $1(7,7 \%)$ & $2(15,4 \%)$ & $3(23,1 \%)$ & $7(53,8 \%)$ & $13(100,0 \%)$ & 0,039 \\
\hline Obesitas & $0(0 \%)$ & $1(20,0 \%)$ & $2(40,0 \%)$ & $2(40,0 \%)$ & $5(100,0 \%)$ & \\
\hline Total & $2(3,2 \%)$ & $8(12,9 \%)$ & $10(16,1 \%)$ & $42(67,7 \%)$ & $62(100,0 \%)$ & \\
\hline
\end{tabular}

Berdasarkan table 4. hasil penelitian menunjukan bahwa siswi dengan indeks massa tubuh (IMT) normal sebagian besar memiliki kebugaran jasmani baik sekali sebanyak 30 orang $(78,9 \%)$, sedang 4 orang $(10,5 \%)$, baik 3 orang $(7,9 \%)$, kurang 1 orang $(2,6)$. Indeks massa tubuh (IMT) overweight memiliki kebugaran jasmani baik sekali sebanyak 7 orang $(53,8 \%)$, baik 3 orang $(23,1 \%)$, sedang 2 orang $(15,4 \%)$, kurang 1 orang $(7,7 \%)$. Indeks massa tubuh (IMT) underweight memiliki kebugaran jasmani baik sekali sebanyak 3 orang $(50,0 \%)$, baik 2 orang $(33,3 \%)$, sedang 1 orang (16,7\%). Indeks massa tubuh (IMT) obesitas memiliki kebugaran jasmani baik sekali sebanyak 2 orang $(40,0 \%)$, baik 2 orang $(40,0 \%)$, sedang 1 orang $(20,0 \%)$ dan tidak ada siswi yang mengalami obesitas yang tidak dapat diuji.

Untuk mengetahui ada atau tidak hubungan antara indeks massa tubuh (IMT) dengan kebugaran jasmani pada siswi SMA 2 di Tabanan pada usia 15-17 tahun maka dilakukan uji statistik dengan menggunakan Chi Square Test dimana nilai $p=0,039$ dan nilai $p$ tersebut kurang dari 0,05 yang berarti terdapat hubungan antara kedua variable yaitu indeks massa tubuh (IMT) dengan kebugaran jasmani pada siswi SMA Negeri 2 di Tabanan.

Hasil penelitian dari 62 sampel siswi dikelompokkan ke dalam 3 kategori usia. Kategori usia terbanyak ialah pada usia 16 tahun yaitu sejumlah 42 siswi (67,7\%), urutan kedua pada usia 15 tahun sejumlah 12 siswi $(19,4 \%)$ dan usia 17 tahun sejumlah 8 siswi (12,9\%). Hasil penelitian menunjukan bahwa sebagian besar indeks massa tubuh (IMT) dengan kategori normal sejumlah 38 siswi (61,3\%), kategori overweight sejumlah 13 siswi $(41,8 \%)$, kategori underweight sejumlah 6 siswi $(9,7 \%)$, kategori obesitas sejumlah 5 siswi $(8,1 \%)$. Seiring bertambahnya usia akan semakin banyak kebutuhan yang diperlukan oleh tubuh serta latihan atau olahraga untuk melatih kekuatan otot dari kemampuan pulih dari aktivitas. Pertambahan usia akan mempengaruhi fungsi tubuh dengan beban yang berbeda dengan aktivitas yang tidak memungkinkan.

Hasil penelitian pada kebugaran jasmani dari 62 siswi menunjukan bahwa rata-rata kebugaran jasmani yang tertinggi berada pada kategori baik sekali sejumlah 42 siswi (67,7\%), kategori baik sejumlah 10 siswi (16,1\%), kategori sedang sejumlah 8 siswi (12,9\%), dan kategori kurang sejumlah 2 siswi $(3,2 \%)$. Dengan hasil penelitian ialah siswi yang paling banyak terdapat pada kategori baik sekali.

Berdasarkan penelitian indeks massa tubuh (IMT) dengan kebugaran jasmani menunjukan bahwa siswi dengan indeks massa tubuh (IMT) normal sebagian besar memiliki kebugaran jasmani baik sekali sebanyak 30 orang $(78,9 \%)$, sedang 4 orang $(10,5 \%)$, baik 3 orang $(7,9 \%)$, kurang 1 orang $(2,6)$. Indeks massa tubuh (IMT) overweight memiliki kebugaran jasmani baik sekali sebanyak 7 orang $(53,8 \%)$, baik 3 orang $(23,1 \%)$, sedang 2 orang $(15,4 \%)$, kurang 1 orang $(7,7 \%)$. Indeks massa tubuh (IMT) underweight memiliki kebugaran jasmani baik sekali sebanyak 3 orang $(50,0 \%)$, baik 2 orang $(33,3 \%)$, sedang 1 orang $(16,7 \%)$. Indeks massa tubuh (IMT) obesitas memiliki kebugaran jasmani baik sekali sebanyak 2 orang $(40,0 \%)$, baik 2 orang $(40,0 \%)$, sedang 1 orang $(20,0 \%)$ dan tidak ada siswi yang mengalami obesitas yang tidak dapat diuji.

Berdasarkan hasil pengujian data Chi Square Test pada jumlah data penelitian sebanyak 62 responden, ditemukan nilai $p$ yaitu sebesar 0,039 untuk indeks massa tubuh (IMT) dengan kebugaran jasmani sehingga nilai $p<$ 0,05 yang menunjukan ada hubungan antara indeks massa tubuh (IMT) dengan kebugaran jasmani pada siswi SMA 
Negeri 2 Tabanan. Arah hubungan tersebut membuktikan bahwa indeks massa tubuh (IMT) yang obesitas dapat menurunkan kebugaran jasmani pada siswi.

Hasil penelitian ini menunjukan adanya hubungan indeks massa tubuh (IMT) dengan kebugaran jasmani, didapatkan masalah dengan indeks massa tubuh (IMT) obesitas yang menyebabkan kebugaran jasmani kurang baik dan menghambat segala aktivitas yang dilakukan.

Aktivitas jasmani yang dilakukan secara rutin dapat memperoleh berbagai manfaat bagi kesehatan. Aktivitas jasmani dapat berupa kegiatan sehari-hari, dan olahraga yang terpilih. Semua aktivitas yang dilakukan memerlukan asupan makanan sebagai sumber energi pada tubuh. Namun aktivitas yang dilakukan tidak seimbang dengan asupan makanan dan akan mengakibatkan tubuh tidak ideal. Tubuh yang tidak ideal tersebut dapat terjadi karena kekurangan atau kelebihan berat badan. Untuk mengetahui seseorang memiliki tubuh ideal atau tidak dapat dilakukan dengan pengukuran indeks massa tubuh (IMT).

Dalam mencapai indeks massa tubuh (IMT) yang normal tentu diperlukan kontrol untuk dapat menjaga berat badan yang sehat. Salah satunya dengan menimbang berat badan secara berkala. Apabila berat badan naik atau berlebih, maka kurangi berat badan dengan cara mengatur pola makan (2 atau 3 kali dalam sehari) dengan gizi seimbang, perbanyak konsumsi makanan yang sehat terutama sayur dan buah, dan pilihlah makanan yang rendah lemak, hindari alkohol, batasi penambahan garam, natrium dan lemak dalam konsumsi makanan yang dimakan tersebut. Selain pola makan, penambahan aktifitas fisik dan olahraga secara teratur selama 30 menit sampai 1 jam dapat memperingan dan membantu membakar lemak berlebih didalam tubuh. ${ }^{7}$

Kebugaran jasmani mempunyai banyak manfaat terutama untuk melakukan aktivitas sehari-hari. Tubuh yang mempunyai tingkat kebugaran yang baik tidak akan mudah lelah sehingga aktivitas dapat dilakukan dengan baik tanpa ada hambatan dan meningkatkan kapasitas belajar siswa, serta meningkatkan ketahanan terhadap penyakit dan menurunkan angka tidak masuk ke sekolah. ${ }^{8}$

Di penelitian ini kebugaran jasmani sangat diperlukan dalam menghadapi persaingan dilingkungan pendidikan. pada hal kebugaran jasmani ini sangat bermanfaat untuk menunjang kapasitas kerja fisik anak yang pada akhirnya diharapkan dapat meningkatkan prestasinya. Sedangkan setelah saya melakukan penelitian, dengan hasil indeks massa tubuh (IMT) normal itu lebih banyak dibandingkan dengan yang underweight, overweight, dan obesitas. Untuk kebugaran jasmani memiliki nilai tertinggi pada kategori baik sekali dibanding baik, sedang, dan kurang, untuk itu disimpulkan bahwa indeks massa tubuh (IMT) dan kebugaran jasmani siswi SMA Negeri 2 Tabanan normal dan sangat baik.

Melihat dari hasil penelitian ini, dapat di jelaskan bahwa siswi SMA Negeri 2 Tabanan memiliki kebugaran jasmani yang sangat baik dengan indeks massa tubuh (IMT) normal, dengan demikian dapat dipertahankan dan ditingkatkan kembali. Supaya segala aktivitas yang dilakukan baik di sekolah maupun diluar sekolah tetap terjaga dan selalu aktif dan efisien. Apabila kebugaran jasmaninya baik sekali dan memiliki indeks massa tubuh (IMT) normal, bukan hanya aktivitas yang dilakukan saja yang bagus, aktif, tanggap, tetapi juga mempengaruhi tingkat prestasi siswi SMA Negeri 2 tabanan yang akan berdampak baik untuk mereka serta sekolah juga bangga memiliki siswa-siswinya yang berprestasi, aktif disagala bidang.

Perkembagan teknologi yang serba canggih menjadi salah satu penyebab beralihnya aktivitas dinamis menjadi statis yang akan menjadi penyebab menurunnya tingkat kebugaran jasmani seseorang, dengan demikian hasil dari penelitian ini berbanding terbalik karena hasil yang didapatkan pada saat penelitian ialah indeks massa tubuh (IMT) normal sebanyak 38 orang sedangkan untuk yang obesitas sebanyak 5 orang, underweight sebanyak 6 orang, overweight sebanyak 13 orang. Untuk kebugaran jasmani didapatkan hasil yang paling banyak pada kategori baik sekali sebanyak 42 orang, baik sebanyak 10 orang, sedang sebanyak 8 orang dan kurang sebanyak 2 orang. Dengan hasil demikian terlihat bahwa siswi SMA Negeri 2 tabanan memiliki kebugaran jasmani dan indeks massa tubuh (IMT) yang normal dan sangat baik, dikarenakan siswi SMA Negeri 2 tabanan memiliki tambahan aktivitas fisik lain yang dapat mempengaruhi kebugaran jasmani ialah melaksanakan senam pagi bersama setiap 2 kali seminggu, dan di sekolah SMA Negeri 2 tabanan ini mengajarkan untuk selalu sarapan pagi sebelum sekolah, makan makanan yang sehat supaya asupan tubuh seimbangan dengan aktivitas yang dilakukan disekolah dan diluar sekolah, serta ada ekstrakurikulernya ialah kegiatan non pelajaran formal yang dilakukan siswa-siswi SMA Negeri 2 Tabanan yang umumnya di luar jam belajar kurikulum standar.

Penelitian yang dilakukan di Jakarta Barat menunjukan bahwa dari 130 remaja putri 47,7\% diantaranya mengalami distorsi terhadap citra tubuh mereka. Distorsi yang dimaksud adalah anggapan keadaan tubuh remaja tidak sesuai dengan kondisi yang sebenarnya. ${ }^{9}$ Studi longitudinal yang dilakukan pada remaja putri dan putra norwegia menyatakan bahwa remaja putra mempunyai gambaran citra tubuh yang lebih baik dibandingkan dengan remaja putri. Penelitian ini juga menyatakan bahwa remaja yang memiliki IMT yang tinggi cenderung untuk memiliki kepuasaan terhadap tubuh rendah. ${ }^{10}$ Remaja yang beresiko untuk terkena obesitas atau overweight menunjukan hasil yang tinggi untuk ketidakpuasan terhadap citra tubuh mereka. Sebanyak $90 \%$ remaja putra dan $91,7 \%$ remaja putri yang overweight di Porto merasa tidak puas dengan citra tubuh mereka. Selain itu, 18,8\% remaja putra 44,8\% remaja putri yang termaksuk normal mempunyai keinginan untuk lebih kurus lagi. ${ }^{11}$

\section{SIMPULAN}

Berdasarkan hasil penelitian yang telah dilakukan maka dapat disimpulkan bahwa terdapat Hubungan antara indeks massa tubuh (IMT) dengan kebugaran jasmani.

\section{DAFTAR PUSTAKA}

1. Riset Kesehatan Dasar. 2013. Badan Penelitian dan Pengembangan Kesehatan Kementrian Kesehatan RI. Jakarta

2. Sharkey, Brian. J. 2003. Kebugaran dan Kesehatan. PT Raja Grafindo: Jakarta, pp 31. 
3. Kemenkes, 2013. Available: http://www.depkes.go.id/resources/download/ general/Hasil\%20Riskesdas\%202013.pdf diakses tanggal 2 januari 2015.

4. Andriani R, 2016. Hubungan Antara Indeks Massa Tubuh dan Aktivitas Fisik dengan Volume Oksigen Maksimum. Surakarta: Fakultas IImu Kesehatan UMS.

5. Annas M, 2011. Jurnal Media IImu Keolahragaan Indonesia. Universitas Negeri Semarang 2011.

6. Centers for Disease Control and Prevention. Youth risk 21.behavior surveillance scale (YRBSS). [series online] 2013 [cited 1 Desember 2013]. Available from: URL: http://www. cdc.gov/HealthyYouth/yrbs/

7. Chathuranga R, Prasanna G, Prasad K, Nalinda A, Sithira T, Praveen T.2013. Relationship between Body mass index (BMI) and body fat percentage, estimated by bioelectrical impedance, in a group of Sri Lankan adults: a cross sectional study. BMC Public Health. 13:797.

8. Sulistiono AA, 2014. Kebugaran jasmani siswa Pendidikan Dasar dan Menengah di Jawa Barat. http://dx.doi.org/10.24832\%2Fjpnk.v20i2.140

9. Samosir, inge arissa. 2008. Hubungan antara citra tubuh, pola konsumsi, dan aktivitas fisik dengan status gizi remaja putri SMP kristoforus 2 jakarta barat. Skripsi

10. Holsen, Inggrid, Diane Carlson Jones, Marianne Skogbrott Birkeland, 2012. Body image satisfaction among Norwegian adolescents and young adults:A longitudinal study of the influence of interpersonal relationships and BMI. Elsevier: Body Image,9,201-208

11. Gaspar, Marisa J. Mointeiro, Teresa F. Amaral, Bruno M.P.M. Oliveira, Nuno Borges. 2011. Protective effect of physical activity on dissatisfaction with body image in children e A cross sectional study. Psychology of Sport and Exercise, 12,563-569 